\title{
RE-SHAPING KING LEAR: SPACE, PLACE, COSTUME, AND GENRE
}

\author{
MICHAEL HATTAWAY* \\ New York University in London, UK
}

\begin{abstract}
Performance studies must enjoy parity of esteem with critical studies because they remind us of the plurality of "readings" that are generated by a Shakespearean text. Shakespeare seems to have apprehended this when, in Othello, he used a nonce-word, "denotement", which applies to Othello's reading of his wife in his mind's eye. I examine other sequences in which we watch a character "reading" on-stage or imagined action, in Hamlet, Titus Andronicus, Cymbeline, Richard II, and Troilus and Cressida. In Hamlet this involves re-reading as well as generic displacement, which, I argue, is a way of rendering inwardness. As I test case, I analyse a production of King Lear by Shakespeare's Globe, on a fairground stage, in which the king reshaped himself, became a folkloric figure, like a figure in Nashe's Summer's Last Will and Testament. The play itself was thus, indecorously, reshaped as "The Tale of King Lear". "Dramatic truth", therefore, in no way depends upon theatrical "realism".
\end{abstract}

Keywords: critical and performance studies; heterocosms and theatrical locations; generic decorum and inwardness; embedded descriptions; denotement; seeing and reading; King Lear; fairground theatres; "folk-drama", truth and realism.

\section{INDUCTION}

I want to talk about performance as well as about performance studies, but immediately I must gloss a seemingly very straightforward statement. This is the gloss: within living memory, critical studies and performance studies were held to be categorically different - and generated fissures in university departments of English in the U.K. By definition, performance studies imply a plurality of meanings or readings. In contrast, critical studies, long linked to textual

\footnotetext{
* hattaway1@mac.com
} 
scholarship, sought to generate something fixed and definitive. You can see this in older performance histories, like those of Marvin Rosenberg, who maintained that there are categoric differences between the representation of something essentially stable, an established text (itself now an outmoded concept), and an adaptation. The tug of traditional literary scholarship can be easily felt.

When it comes to the poetics of theatre, we realise that "action is eloquence" (Volumnia to Coriolanus [3.2.76)]), and that the largely unrecorded or undetermined languages or semiotics of early performance were welded on to the processes of the theatrical rendering of written texts. Moreover, audiences do not simply "see": words, concepts, ekphrases, theatrical images, and visual signs are, in the working-houses of spectators' thoughts, dissolved, diffused, and recombined in a complex process of re-creation. The results, of course, are various (Bruner loc. 64ff), and the "base" of a performance, an authoritative text, therefore seems less important.

I want to be regressive: to import to critical studies some of the insights generated by performance studies. This will involve some examples of contextualisation: texts, like performances, can and need to be read differently on different occasions, words can be made to work on our imaginary forces in different ways. As we shall see, in a playhouse, generic expectations can be conspicuously displaced, and theatrical forms can overwrite dramatic forms. To tweak a famous metaphor of Keats: like an author, a text, in the manner of a chameleon (Keats 172), takes its colour from its context.

As teachers of Shakespeare, in my experience we find there is a lot of methodological groundwork to be done in our classrooms. The heterocosms Shakespeare creates and the theatrical sets that establish them are "texts" as well as "worlds". They emerge as much from what we hear and interpret as from what we see-and there is seldom a need for an on-stage gondola in the Venetian plays to authenticate a specious attempt at verisimilitude, or to prod imagination towards memory. Moreover, instead of allowing our students to look for traces of truth to life and to pick up default psychological concepts such as "'identification' with characters", we need to direct them to linguistic tropes- "reading", etc. These rapidly demonstrate the unsatisfactoriness of modern psychological categories and of motive-hunting. We inhabit an imagesaturated culture, but much of what is purveyed is sensational, flashed up to be seen, not held still for contemplation.

To this end I want to look closely at, first, embedded descriptions in Shakespearean texts-Shakespeare always gets there before us-at moments that depict or suggest processes of witnessing or reading the actions or performances of public and private life. These poetic explorations may suggest something about the way the perceiving mind may work. Second, I want to pick out moments of incongruity, when Shakespeare suddenly violates generic decorum, injects comedy into tragedy, which, I postulate, is a tool for exploring 
inwardness (Mauss 1995). I conclude with some remarks about theatrical indecorum - not to disparage but to praise a recent production of King Lear on a fairground stage.

\section{DENOTEMENTS}

First, a keyword, but a difficult one. In Othello, Iago narrates to Cassio how the doting general, who later will naively claim ocular proof (3.3.361) of his wife's infidelity, has "devoted and given up himself to the contemplation, mark, and denotement of [Desdemona's] parts and graces" (2.3.288-9, emphasis added). The word "denotement", which is a Shakespearean neologism, crops up again in the next act (at least in the Q1 [1622] version): "Such things ... in a man that's just, / They're close denotements, working from the heart, / That passion cannot rule" (3.3.123-5). I take "passion" to be the subject of "rule": the meaning, I suggest, is that both "denotements" are intimations or proto-narratives: the former strung together by Othello when he is blissfully in love, and the latter comprised of suspicious intimations, originating in the heart and therefore irrational, and unsusceptible to another irrational force, the healing power of love.

Unfortunately, each passage contains a crux, but not, I think, one that harms my argument. "Dilations", the word that occurs in place of "denotements" in both Q2 and F of the second quotation, could also designate half-formed stories - part of $O E D$ 's gloss on that word is "token, sign". They are, I suggest, akin to "unfoldings", a recurrent word in Shakespeare- "implicate", of course, etymologically means to fold or wrap up.

Very tentatively, I propose that a "denotement" may also be akin to what Richard Dawkins called a "meme", a "replicator ... [something] that conveys the idea of a unit of cultural transmission, or meaning, a unit of imitation" (Dawkins 192). It is something like a gene or a virus. We might prefer to use "commonplace", but, unlike a commonplace, a meme may operate at a sub-or pre-verbal level.

The first meaning of the verb "denote" recorded in $O E D$ is a transitive one, "To note down; to put into or state in writing; to describe". My paper rests on the assumption that this has to do with the production as well as the reception of meaning. Moreover, the device, to use Joseph Conrad's formula, helps us not only to feel but also to see what and how stage characters see (Ryan).

However, the word does not occur elsewhere in the canon, and Literature Online does not find it again until the nineteenth century in texts that

\footnotetext{
${ }^{1}$ For this crux see Shakespeare, William. Othello. Ed. Sanders, Norman. Cambridge: Cambridge University Press, 1984, 190 long note, 3.3.124-5. Print. See also Parker 1985.
} 
generally had some connection with Shakespearean ones. In our context, therefore, it is almost a nonce word, but the Q1 text suggests that it may have come to the surface of Shakespeare's mind twice, perhaps impelled upwards by his remembering his composition of Much Ado about Nothing ("noting", of course). Patricia Parker has recently pointed out that the verb "note" can also mean "stigmatise" or "accuse" - and invokes the obscene pun on "not[h]ing" for the vagina (Parker 2014).

All this suggests that Shakespeare, if not Othello, was well aware that seeing offered not simple ocular proof, but was part of "seeing as", a longer process of "marking" or noticing, of reading, and of interpreting (McConarchie and Hart 2006). I think too that he knew that the interpretation of particular words or moments is partly fashioned by the stories in which they occur: it makes sense to say that Iago is describing how Othello may be contemplating or rewriting images of Desdemona embedded in the narrative of his wooing and wedding of her, and also, perhaps, be summoning into his mind's eye other less happy narratives, of feminine role-playing or infidelities. These stories or imaginings, I submit, are "supplements" in the way Derrida, building upon Rousseau (Culler 11), defined them, both accretions and substitutions (Derrida 200).

Imagination is only not a deceptive "fancy" clipped onto or out of real experience as Theseus defines it in A Midsummer Night's Dream, but is rather associated with the creative power of story-telling that witnesses more than the images of fancy - see the polite but firm rejoinder of Hippolyta to her husband to attend to stories as well as images or ideas (5.1.1-27).

Most Renaissance definitions of "imagination" or "fancy" categorise it as an organ that has the function of a mirror or glass that reflects images, objects of sense, in order to submit them to what Fulke Greville in 1633 called "understanding's clear intelligence" (Greville 564; see also Rossky). Imaginative fictions, composed of words, long continued to disconcert literary theorists.

I hope you do not think I am being too fanciful to claim that Danny Boyle's wonderful opening of the London Olympics in 2012 was a series of "denotements", of thinking with brief narratives. I shall return to another much earlier pageant: indeed denotements may be the mode of pageants.

Almost a century ago, Ogden and Richards, in The Meaning of Meaning (1923), put into wide circulation a distinction between "denotation" and "connotation"- a distinction that can, in fact, be tracked back to John Stuart Mill (OED, denotation, n. §5). I would submit that Shakespeare was aware of the way the poetic mind supplemented a simple image or word. However, this citation is valuable only per contra: Shakespeare's "denotement", having to do with the exploration of affective or emotional associations, is closer to the usual modern meaning of "connotation". 
Second, a key passage in which the phenomenon I am calling denotement occurs in little: in the final Chorus of Henry $V$, the spectators are thus enjoined to conjure up the scene of Henry's arrival in London, back from Agincourt:

... now behold,

In the quick forge and working-house of thought,

How London doth pour out her citizens.

The Mayor and all his brethren, in best sort,

Like to the senators of th'antique Rome

With the plebeians swarming at their heels,

Go forth and fetch their conqu'ring Caesar in ...

(5. Chorus, 22-8; emphasis added)

What is interesting here is that Shakespeare, similarly, does not request his auditors simply to "see" or "imagine" the Londoners in their mind's eye, but to see them "as" something else, in this case a Roman triumph. It is significant that Shakespeare uses the present tense in the extension of the simile "Go forth and fetch their conqu'ring Caesar in": Plantagenet London and Republican Rome coexist in the same mental frame.

But it is even more complicated than that, for, later in this passage, Shakespeare presages the hoped-for arrival of the Earl of Essex, back from quelling the Tyrone insurrection in Ireland, "bringing rebellion broachèd on his sword" (line 32). Shakespeare adds another image that needs to be read, also a third place, also a third time, the Tudor present.

In the playhouse, "seeing" is often "seeing as". Alan Dessen demonstrated the ways in which details of dress or stock properties were specified in stage directions for entrances and were often followed by the formula "as from": "in his gown as from his study", "as out of the woods, with bow and arrows" (Dessen and Thomson 13-14). The objects are signs to be decoded. Moreover, particularly in the case of comedy, and even more particularly in the case of players who had become celebrities, audiences were, it seems, possessed of a double awareness, were encouraged to see the player as himself and as the deployer of conventions for the character he was playing. Indeed, all performances, comic and tragic, were perfused with the ludic: as Freud remarked in "Creative Writers and Day-Dreaming" [1908], "The opposite of play is not what is serious but what is real" (Freud 421).

Now, one of the advantages of verse drama is that it allows for the dislocation of space-time structures: the intrusions into the Henry $V$ chorus invoke three times and three places simultaneously. The passage reminds of us two things: first of the degree of intellection that takes place in our mental "working-houses" (workshops) as what is apprehended is converted into something to be comprehended and, second, of the opacity of language, the way 
it is used not just to "paint a picture" or represent reality but to tell or explain. The mind's eye is categorically different from the body's eye: it is certainly more than just "imagination" in the sense of an image-forming machine, serving the fancy or feeding desire.

Twenty-six years ago Seamus Heaney, with insouciant brilliance, summed up the inventive and creative facility of the poetic and workaday imagination in the two-word title of his 1991 collection of verse, Seeing Things. What is "real" is what is invented.

\section{GENERIC DISPLACEMENT}

A word, a passage, two genres: we now invoke Jerome Bruner's discussion of the psychology of genre in Actual Minds, Possible Worlds. "Genre", he writes,

seems to be a way of both organizing the structure of events and organizing the telling of them - a way that can be used for one's own storytelling or, indeed, for "placing" stories one is reading or hearing. Something in the actual text [in our case, the text created by Othello running his story of Desdemona through his mind] 'triggers' an interpretation of genre in the reader, an interpretation that then dominates the reader's own creation of what Wolfgang Iser calls a virtual text". (Bruner 89-90)

Within the play, Othello's invented narrative is a "type" of this.

A paradigmatic and extended example of this is the Pyrrhus sequence in Hamlet, comparatively overlooked, but which has always seemed to me, by its play with the psychology of genre, to complement the great soliloquies and to speak of what is within, "which passeth show" (1.2.85). The arrival of the players sparks a memory from a favourite speech from a play in their repertoire - a denotement. This speech derives from Dido's narrative of the fall of Troy in Book 2 of the Aeneid, and Hamlet begins to replay the lines: "The rugged Pyrrhus, he whose sable arms / Black as his purpose, did the night resemble ..." (2.2.390-91). I can agree only partly with Philippa Berry who suggests Hamlet here casts himself in Dido's role as choric listener (Berry 6061). For is not Pyrrhus Hamlet's Doppelganger, a figure from heroic epic- "the poetry of the past"-who interrupts the drama - "the poetry of the present" (Wellek and Warren 128)? He occupies Hamlet's mind, the textualised antagonist of the Ghost, and Hamlet's re-reading of the image impels him to recognize that revenge for honour is a species of murder.

In another play, when Troilus, with Ulysses by his side, sees Cressida in Diomed's company, he offers two readings of the scene:

This she? No, this is Diomed's Cressida.

If beauty have a soul, this is not she. 
If souls guide vows, if vows be sanctimonies, If sanctimony be the gods' delight,

If there be rule in unity itself,

This is not she. O madness of discourse,

That cause sets up with and against thyself!

Bifold authority, where reason can revolt

Without perdition, and loss assume all reason

Without revolt! This is and is not Cressid ...

Instance, $\mathrm{O}$ instance, strong as Pluto's gates:

Cressid is mine, tied with the bonds of heaven.

Instance, $\mathrm{O}$ instance, strong as heaven itself:

The bonds of heaven are slipped, dissolved, and loosed,

And with another knot, five-finger-tied,

The fractions of her faith, orts of her love,

The fragments, scraps, the bits and greasy relics

Of her o'er-eaten faith, are bound to Diomed. (5.2.136-59)

One reading looks forward to a denouement of integration, the second to one of disintegration

T.S. Eliot famously complained of Othello's self-dramatising and of his "cheering himself up" (Eliot 130). But in Shakespearean texts, emotional pressure often seems to have generated a kind of "ecstasy", standing outside oneself, seeing oneself as written by someone else. Othello had cast himself as an epic or at least a romantic hero in the tales of anthropophagi and the like with which he had wooed Desdemona. At the end, Othello quotes from another epic poem, this time the invocation to Lepanto, written by the King himself (an extraordinarily jingoistic text, written in ballad metre!) and published in 1591 . He boasts that, in an earlier life in Aleppo, he had slain one of the "Circumsizèd turbaned Turks" (line 11), of the tribe that had been defeated by the "baptised race", a coalition of Christians, in retaliation for the loss of Cyprus a few months earlier.

I sing a wondrous work of God,

I sing his mercies great,

I sing his justice heere-withall

Powered from his holy seat.

To wit, a cruel Martial war,

A bloody battle bold,

Long doubtsome fight, with slaughter huge

And wounded manifold.

Which fought was in Lepanto's gulf

Betwixt the baptiz'd race

And circumsisèd Turban'd Turks

Rencountring in that place. $(1-12)^{2}$

\footnotetext{
${ }^{2}$ http://literature.proquest.com.eresources.shef.ac.uk/searchFulltext.do?id=Z300404256\& childSectionId=Z300404256\&divLevel $=3 \&$ queryId $=2953464397857 \&$ trailId $=157399 \mathrm{~A}$ 4CC3\&area=poetry\&forward=textsFT\&queryType=findWork. Web. 18.1.2017
} 
Even though the allusion is fleeting, it may be that Othello is claiming that his self-slaughter is Godly work, the dispatching of a Moor - the word could mean "Muslim". (Ballads reappear at the end of my paper.)

In an early work, Titus Andronicus, Lavinia's uncle Marcus offers an extended and "virtual" reading of his niece's maimed body, first as a tree, then as a fountain. He turns from dialogue to the creation of two emblems, like those that appear in emblem books, in which image and verse are fused:

Speak, gentle niece, what stern ungentle hands

Hath lopped and hewed and made thy body bare

Of her two branches, those sweet ornaments

Whose circling shadows kings have sought to sleep in,

And might not gain so great a happiness

As half thy love. Why dost not speak to me?

Alas, a crimson river of warm blood,

Like to a bubbling fountain stirred with wind,

Doth rise and fall between thy rosèd lips,

Coming and going with thy honey breath. (2.4.15-25)

Another way of putting this to say that Marcus over-writes the body of Lavinia with a "denotement", Ovid's story of Philomena, raped by Tereus, a story that fills a tirade of 47 lines.

But sure some Tereus hath deflowered thee

And, lest thou shouldst detect him, cut thy tongue...

Fair Philomel, why she but lost her tongue

And in a tedious sampler sewed her mind.

But, lovely niece, that mean is cut from thee.

A craftier Tereus, cousin, hast thou met,

And he hath cut those pretty fingers off

That could have better sewed than Philomel. (2.4.26-7 \& 41-43)

As that were not enough, Marcus (Shakespeare) follows with two ekphrases, an allusion to Philomel's tapestry that told the story of her rape, and a description of the heavenly sounds that Lavinia might have played upon a lute, or sung to tame the monstrous brothers, Chiron and Demetrius, just as Orpheus had charmed Cerberus:

$\mathrm{O}$, had the monster seen those lily hands

Tremble like aspen leaves upon a lute

And make the silken strings delight to kiss them,

He would not then have touched them for his life.

Or had he heard the heavenly harmony

Which that sweet tongue hath made, 
He would have dropped his knife and fell asleep,

As Cerberus at the Thracian poet's feet. (2.4.44-51)

Each of these four passages, I venture, are discrete denotements. It is as though the young Shakespeare was determined to resist any call of realism, based upon Marcus' direct observation of the scene. Rather, by setting out these triggered descriptions and events, he essays both a kind of psychological inwardness and an evocation of alternative conventions for rendering not just Lavinia, but all that was taken to be feminine.

Similarly, in Cymbeline, Innogen reads what she takes to be Posthumus' headless body - in fact of course it is Cloten's - in effect, emblematising it:

$$
\text { O gods and goddesses! }
$$

These flowers are like the pleasures of the world,

This bloody man, the care on't. (4.2.294-6)

The sequences may work in a way similar to Manet's Déjeuner sur l'herbe where a "classical" nude sits incongruously between some bourgeois gentlemen, drawing attention to this problematic. There too, hybridity, of domestic and classical realism, creates a kind of inwardness. Is the woman at ease, does she fear some distress? Is she a prostitute-there were many in the Bois de Bologne - and is the respectability of the gentlemen's dress a cover for hypocrisy, their wish for disreputable sex?

Before we turn to King Lear, the whole of which was reshaped in a recent production, I want to look at 5.3. of Richard II. In 5.2 Bullingbrook's succession seems assured. But his discussion with Hotspur concerning the unruliness of his son, Prince Hal, is interrupted by Aumerle. Aumerle's father, the Duke of York, had found treasonous papers about his son's person. He arrives shortly after his son, in fact to demand condign punishment for him. The Duchess of York arrives to plead for his life:

Bullingbrook: What shrill-voiced suppliant makes this eager cry?

Duchess of York: A woman and thy aunt, great king. 'Tis I.

Speak with me, pity me, open the door!

A beggar begs that never begged before.

Bullingbrook: Our scene is alter'd from a serious thing,

And now changed to "The Beggar and the King".

My dangerous cousin, let your mother in.

I know she is come to pray for your foul sin. (5.3.74-81)

Again, a change of genre creates a degree of inwardness, folk comedy invades history, and Bullingbrook is reminded of the sad stories of all those who wore the hollow crown. He becomes the "type" of a king threatened by insurrection at 
court and the type of all fathers whose sons wish to supplant them. He is also the type of a king who might appear in a ballad-tale, like the story of "King Cophetua and the Beggar Maid" (see Shakespeare 1984, 5.3.79n). (In this context we may remember Goneril's exclamation 'An interlude' (Shakespeare 2005, 5.3.90) when Albany points out to Regan that Goneril was "subcontracted" to Edmund before her.)

\section{RECONTEXTUALISING KING LEAR}

About a year ago I went to New York to give a talk on the staging of Shakespeare on booth or fairground stages before a performance of King Lear. The play had been translated into this mode by Shakespeare's Globe, and then transported from London to NYU's Skirball Center for the Performing Arts.

Lear was written in 1605 and probably first performed at the original Globe. We know, from the title-page of the 1608 Quarto, of a later performance "before the King's Majesty at Whitehall upon St Stephen's night [26 December, 1606] in Christmas Holidays". From that date and until 1610, records indicate that the King's Men were regularly travelling-sometimes during times of plague - so Lear may have been played in the provinces on a small portable stage, as well as, at Gouthwaite in Yorkshire, in the hall of a great house that belonged to a recusant family (Shakespeare 2005, 32).

I began my Manhattan talk by addressing the problematic of the play's genre - history (the Q title) or tragedy (the F title) — and remarking — because I had already seen the London version - that what Bill Buckhurst the director had done, to suit his fairground staging, was to reshape the play into "The Tale of King Lear". Theatrical transition created textual translation.

When I had finished, there was a Q and A. Out of the blue I received a volley of insults from an elderly British expat, very short, perhaps an actor or theatre critic of the old school. "Are you saying this is not a 'tragedy' but a 'tale'?" he shouted. "You call yourself a professor: where do you profess this nonsense?" He compounded the insult by congratulating the man next to him: "You're lucky you were late. You didn't have to listen to so much of this balderdash ..."

What this shows is that Aristotelian categories and generic hierarchies have a remarkable staying power. Making King Lear into a play for and of the people did not, for me, as it did for him, take away the power of the play's great moments.

There was, of course, change: As Jerome Bruner writes:

For while it may be the case that in the time-smoothed folktale story-stuff determines character (and therefore character cannot be central), it is equally 
true that in the "modern" novel plot is derived from the working out of character in a particular setting. ( Bruner, loc. 274/2507 )

My choleric interlocutor obviously expected a tragedy with a tragic hero.

The mode of this production was more presentational than representational, emphasising role rather than character. The company was comprised of only eight players: doubling, of course, adds new dimensions to the action and moves the focus further from the central character. Joseph Marcell, a black actor, played Lear, Bethan Cullinane, as is frequent, doubled Cordelia and the Fool, John Stahl doubled Gloucester, Albany, and the Doctor. Costumes were contemporary work-a-day kit, but with token gowns, properties etc. Dress fixed roles rather than personalities - Goneril and Regan had identical gowns, two "nasty women" (thank you, Donald Trump!). Costume racks stood on the stage, thunder sheets were visible from the side, and the sound of the storm was amplified by wind sound on cymbals.

We all know about plays within plays: at both the London Globe and in New York, Globe on Tour built a stage upon the stage, adding a metatheatrical dimension to the performance. Everything gained another set of inverted commas around it: this was a representation of a representation: there was no illusion, but we saw a combination of immediacy and the kinds of allusion I have been describing. This mode was created by fusing the playing space (used by actors) with the performance space (part of which was occupied by the audience). At the Globe the players, including Lear, came down from stage into yard to chat and josh with audience members. The production was open to a range of interpretations, players demonstrated rather than impersonated, and personality traits were partly brought into being by the presence of the audience.

This Globe Lear began with a sung ballad - the players were musicians with trumpet and squeezebox; another ballad was sung before "Thou, Nature, art my goddess ..." "[1.2]). By combining the roles of balladeer with king, Lear was a presenter, of himself. "Present" is the verb used multiple times in "Pyramus and Thisbe", and Edgar speaks of "presented nakedness" (2.3.11). This too signalled, perhaps, that this is indeed "the tale of King Lear".

The photograph of Lear on the programme shows the king as Cordelia describes him in 4.3:

Alack, 'tis he: why, he was met even now,

As mad as the vexed sea, singing aloud,

Crowned with rank fumitor and furrow-weeds,

With burdocks, hemlock, nettles, cuckoo-flowers,

Darnel, and all the idle weeds that grow

In our sustaining corn (4.3.1-8)

In the Dover Cliff scene, Edgar's line "Bear free and patient thoughts. But who comes here?" (4.5.80) is interrupted by the stage direction: "Enter Lear", to 
which many editors have added the detail "mad, crowned with weeds and flowers". The performance thus kindled, despite its sombre subject, a mood of festivity and reassurance as archetypal patterns fused with calendrical ones that evoked as much permanence as mutability.

For the madness sequence, Lear, perhaps composing a denotement on mutability, had imagined himself as a folktale king, or perhaps a pageant figure, like that being presented by a historical jester, in Thomas Nashe's Summer's Last Will and Testament of 1592 (printed in 1600). We remember that in early modern English the word 'shape' could mean a theatrical costume- $O E D$ records it having this meaning from 1604 (OED, shape, n. §8a). Bruner develops from Greimas the concept of "dual landscape": "a primitive or irreducible feature of story ... in that it occurs jointly on the plane of the action and in the subjectivity of the protagonists" (Bruner, loc. 274/2507). That would fit this moment.

In the Nashe pageant, the ghost of Will Summers, fool or jester to Queen Elizabeth - and in some ways like the Fool in King Lear or the King himselfcalls his servants to account (OED, shape, n. §8a). Here is his Summer's selfpresentation. Like Lear, Summer is oppressed by the end of his reign or lease, a feeling heightened by his descant upon ubi sunt texts:

Summer: What pleasure alway lasts? No joy endures:

Summer I was, I am not as I was;

Harvest and age have whit'ned my green head:

On Autumn now and Winter must I lean.

Needs must he fall whom none but foes uphold.

Thus must the happiest man have his black day:

Omnibus una manet nox, et calcanda semel via lethi .

This month have I lain languishing a-bed,

Looking each hour to yield my life and throne;

And died I had in deed unto the earth,

But that Eliza, England's beauteous Queen,

On whom all seasons prosperously attend,

Forbad the execution of my fate,

Until her joyful progress was expired.

For her doth Summer live, and linger here,

And wisheth long to live to her content:

But wishes are not had when they wish well.

I must depart, my death-day is set down:

To these two must I leave my wheaten crown.

So unto unthrifts rich men leave their lands,

Who in an hour consume long labour's gains.

(Nashe 150-1, emphasis added)

Lear had reread himself and had reshaped or refashioned himself accordingly. 
For me it worked. On a booth stage a Lear needs to work harder to be certain of a special sort of stillness for his death, unaided by lighting or music. He had to transition from the raw impact of his entrance with Cordelia's body to his final line "Look there, look there" (5.3.284). In this production, rather than seeing a looking glass cloud over or a feather stirred by Cordelia's breath, he seemed to be reading, reading another imagined denotement, his daughter's spirit ascending to heaven-from the stage.

\section{Works Cited}

Berry, Philippa. Shakespeare's Feminine Ending: Disfiguring Death in the Tragedies. London: Routledge, 1999. Print.

Bruner, Jerome S. Actual Minds, Possible Worlds. Kindle ed. Cambridge, Mass.; London: Harvard University Press, 1986. Web.

Culler, Jonathan. Literary Theory: A Very Short Introduction. Oxford: Oxford University Press, 1997. Print.

Dawkins, Richard. The Selfish Gene. Oxford: Oxford University Press, rev. edn. 1989. Print.

Derrida, Jacques. Of Grammatology. Trans. Spivak, Gayatri Chakravorty. Baltimore Md 1976. Print.

Dessen, Alan C., and Leslie Thomson. A Dictionary of Stage Directions in English Drama, 1580-1642. Cambridge, U.K.; New York: Cambridge University Press, 1999. Print.

Eliot, T.S. "Shakespeare and the Stoicism of Seneca." Selected Essays. London: Faber, 1951 edn. Print.

Freud, Sigmund. Collected Papers Volume 4. New York: Basic Books Inc, 1959. Print.

Greville, Fulke. "A Treatie of Humane Learning." Five Courtier Poets of the English Renaissance. Ed. Bender, Robert M. New York: Washington Square Press, 1969. Print.

Keats, John. "Letter to Richard Woodhouse, 27 October 1818." Letters of John Keats. Ed. Page, Frederick. London: Oxford University Press, 1954. Print.

Maus, Katharine Eisaman. Inwardness and Theater in the English Renaissance. Chicago: University of Chicago Press, 1995. Print.

McConachie, Bruce A., and F. Elizabeth Hart. Performance and Cognition: Theatre Studies and the Cognitive Turn. London: Routledge, 2006. Print.

Nashe, Thomas. The Unfortunate Traveller and Other Works. Ed. Steane, J.B. Harmondsworth: Penguin Books, 1972. Print.

Ogden, C. K., and I. A. Richards. The Meaning of Meaning. [S.1.]: K. Paul, 1923. Print.

Patricia Parker. 'Shakespeare and Rhetoric: 'Dilation' and 'Delation'." Shakespeare and the Question of Theory. Eds. Parker, Patricia and Geoffrey Hartman. New York: Routledge, 1985. 54-74. Print.

Parker, Patricia. “(De)Noting and Slander'." Shakespeare 450. Paris, 2014. Conference paper.

Shakespeare, William. King Richard II. Ed. Gurr, Andrew. Cambridge1984. Print. 
Shakespeare, William. The Tragedy of King Lear. Ed. Halio, Jay L. Updated ed. Cambridge: Cambridge University Press, 2005. Print.

Rossky, William. "Imagination in the English Renaissance: Psychology and Poetic." Studies in the Renaissance 5.1958 (1958): 49-73. Print.

Ryan, Kiernan. "'Prosper on the Top (Invisible): Power and Perception in Shakespeare." Shakespeare 450. Paris, 2014. Conference Paper.

Shakespeare, William. King Richard II. Ed. Gurr, Andrew. Cambridge1984. Print.

Wellek, Rene, and Austin Warren. Theory of Literature. (Third Edition Reissued.). Harmondsworth: Penguin Books, 1973. Print. 